\title{
Analisis Komunikasi Internal di Kantor Imigrasi Kelas 1 Jakarta Pusat Dalam Meningkatkan Pelayanan Publik
}

\section{Internal Communication Analysis in Improving Public Service at Class 1 Immigration Office Central Jakarta}

\section{G Astria, IA Ratnamulyani, AA Kusumadinata}

Program Studi Komunikasi, Fakultas Ilmu Sosial dan Ilmu Politik

Jl. Tol Ciawi No.1 Kotak Pos 35 Bogor 16720

a Korespondensi: AA Kusumadinata, Email: alialamsyahkusumadinata@gmail.com

(Ditelaah: 20-01-2016; Disetujui: 24-02-2016)

\begin{abstract}
Internal communication is a form of interaction between officers in the office as a factor that affect service to the public. Officers' lack of awareness in providing information causes disappointment and dissatisfaction with many services. Establishing good and effective internal communication is essential to avoid any misunderstanding in organization's internal relations. One Stop Service System is a standard operating procedure of passport services. The problems that exist with the OSS integrated system of passport services; quota determination, the determination of the applicant's arrival date, skipping flow, no refund, and E-passport could not get pass through autogate. This research describes internal communication on how to handle complaints from passport applicants. Special scope of internal communication was conducted by Immigration Traffic Section and Information and Communication Section. This research is a qualitative descriptive study aims to determine the internal communication that includes forms and types of communication as well as the factors and obstacles being held in Immigration Traffic Section and Information and Communication Section. Data collection techniques by means of interviews, observation, and documentation. Informants selection used purposive sampling technique with interactive data analysis techniques models. The results showed that the internal communication happens between the unit sections occurs directly and through the telephone media. The type of result are divided into two parts, namely personal communication and group communication that describes the dimensions of internal communication. The driving factors and barriers that occur are lack of communication, different purposes, and the organization problem while the barriers caused by individual and mechanical obstacles.
\end{abstract}

Key words: Internal Communication, Misunderstanding, One Stop Service

\section{ABSTRAK}

Komunikasi internal merupakan bentuk interaksi antara anggota didalamnya sebagai faktor yang mempengaruhi pelayanan terhadap publik. Kekecewaan dan ketidakpuasan terhadap pelayanan banyak disebabkan kurangnya kesadaran pegawai dalam memberikan informasi. Membangun komunikasi internal yang baik dan efektif merupakan hal yang penting untuk 
menghindari adanya kesalahpahaman di dalam hubungan internal organisasi. Sistem One Stop Service merupakan standar operasional prosedur pelayanan paspor. Permasalahan yang ada di lapangan mengenai sistem pelayanan paspor terpadu OSS; penentuan kuota, penentuan tanggal datangnya pemohon, loncat alur, pembayarannya tidak bisa untuk di uangkan kembali (refund), dan E-Paspor yang tidak bisa melewati Autogate. Penelitian ini mendeskripsikan komunikasi internal mengenai kegiatan penangan masalah komplain dari pemohon paspor. Ruang lingkup khusus pada komunikasi internal ini dilaksanakan oleh Seksi Lalu Lintas Keimigrasian dan Seksi Informasi dan Sarana Komunikasi. Penelitian ini merupakan penelitian deskriptif kualitatif yang bertujuan untuk mengetahui komunikasi internal yang meliputi bentuk dan jenis komunikasi serta faktor dan hambatan yang tengah berlangsung di Seksi Lalu Lintas Keimigrasian dan Seksi Informasi dan Sarana Komunikasi. Teknik pengumpulan data dengan cara wawancara, observasi, dan dokumentasi. Teknik pemilihan informannya menggunakan teknik purposive sampling dengan menggunakan teknik analisis data interaktif model. Hasil penelitian ini menunjukkan, bahwa komunikasi internal yang terjadi di antara unit seksi tersebut terjadi secara langsung dan menggunakan media saluran telepon. Jenisnya terbagi menjadi dua bagian yaitu komunikasi personal dan komunikasi kelompok yang menggambarkan dimensi komunikasi internal. Faktor pendorng dan hambatan yang terjadi dikarenakan kurangnya komunikasi, perbedaan dalam berbagai tujuan, dan problem organisasi sedangkan hambatannya disebabkan oleh hambatan individual dan hambatan mekanis.

Kata kunci : Komunikasi Internal, Kesalahpahaman, One Stop Service

G Astria, IA Ratnamulyani, AA Kusumadinata. 2016. Analisis Komunikasi Internal di Kantor Imigrasi Kelas 1 Jakarta Pusat Dalam Meningkatkan Pelayanan Publik. Jurnal Komunikatio 2(1): Halaman 15-24. 


\section{PENDAHULUAN}

Komunikasi adalah bentuk interaksi manusia yang saling terpengaruh mempengaruhi satu sama lainnya, sengaja atau tidak sengaja. Tidak terbatas pada bentuk komunikasi menggunakan bahasa verbal, tetapi juga dalam hal ekspresi muka, lukisan, seni, dan teknologi, Wiryanto, (2004).

Setiap individu selalu berkomunikasi dan berkeinginan menerima informasi dari orang lain. Hal ini berlangsung karena manusia ingin memenuhi kebutuhan hidupnya sebagai mahluk sosial, oleh karena itu manusia saling bekerjasama sehingga membentuk suatu organisasi.

Komunikasi dilakukan atas dasar pencapaian kepentingan bersama untuk tercapainya tujuan organisasi. Komunikasi dalam sebuah organisasi digunakan untuk menciptakan adanya kesamaan pemahaman antara atasan dan bawahan. Komunikasi yang efektif akan menentukan kelangsungan hidup sebuah organisasi.

Dalam sebuah institusi Pemerintahan untuk menciptakan komunikasi yang efektif tidaklah mudah. Woodruffe dalam Abdullah dan Antony, (2012) mengemukakan bahwa komunikasi internal dalam sebuah organisasi prosesnya tersebut tidak selalu berjalan mulus karena setiap individu memiliki ruang lingkup dan pemahaman yang berbeda terhadap organisasi.

Misunderstanding merupakan Iklim yang terjadi di Kantor Imigrasi Kelas 1 Jakarta pusat. Sebagai sebuah organisasi pelayanan publik, Kantor Imigrasi Kelas I Jakarta Pusat memiliki dinamika komunikasi yang berdeda-beda. Komunikasi internal dipandang sebagai bentuk interaksi antara anggota didalamnya sebagai faktor yang mempengaruhi pelayanan terhadap publik. Misunderstanding yang terjadi antara Seksi Informasi dan Sarana Komunikasi dengan Seksi Lalu Lintas Keimigrasian yaitu mengenai penanganan masalah keluhan maupun komplain dari pemohon jasa Keimigrasian mengenai sistem prosedur pelayanan paspor One Stop Service (OSS).

One Stop Service merupakan standar operasional prosedur sistem pelayanan paspor terpadu yang dituangkan dalam Peraturan Menteri Hukum dan HAM nomor
2 tahun 2014 tentang program Aksi Kementerian Hukum dan HAM tahun 2014 yang diterapkan secara bertahap di seluruh Kantor Imigrasi.

Adapun permasalahan yang ada di lapangan mengenai sistem pelayanan paspor terpadu One Stop Service yang bersumber dari data dokumen dan file Seksi Insarkom 2015 terdiri dari 86 sms, 87 email, 2 website dan 17 surat pernyataan dimulai bulan januari sampai dengan Maret 2015 meliputi; sistem pelayanan paspor terpadu (one stop service) belum bisa melakukan penentuan kuota sesuai kebijakan kantor selanjutnya untuk permohonan melalui sistem online sering terjadi masalah dalam penentuan tanggal datangnya pemohon, terjadi loncat alur, permohonan online yang sudah membayar di Bank BNI namun gagal melakukan proses pelayanan paspor terpadu (one stop service) pembayarannya tidak bisa untuk di uangkan kembali (refund) dan E-Paspor yang tidak bisa melewati Autogate.

Komunikasi dalam organisasi mencakup aktivitas komunikasi secara internal dan eksternal. Komunikasi dilakukan atas dasar pencapaian kepentingan bersama untuk tercapainya tujuan organisasi maka dalam indentifikasi permasalahan diatas diperlukan komunikasi internal yang dilakukan secara timbal balik atau terkoordinasi antara Seksi Informasi dan Sarana Komunikasi dengan Seksi Lalu Lintas Keimigrasian untuk menghindari adanya kesalahpahaman/misunderstanding di dalam hubungan internal yang menyangkut penanganan pertanyaan, masalah keluhan atau komplain. Konsep peningkatkan kualitas pelayanan publik ini dapat ditinjau melalui komunikasi internal yang efektif karena kekecewaan dan ketidakpuasan terhadap pelayanan banyak disebabkan kurangnya kesadaran pegawai dalam memberikan informasi.

\section{METODE PENELITIAN}

Penelitian ini dilaksanakan di Kantor Imigrasi Kelas 1 Jakarta Pusat. Penelitian ini 
bersifat deskriptif kualitatif yaitu suatu jenis penelitian yang berusaha memaparkan dan menggambarkan obyek yang diteliti berdasarkan realita. Penelitian dilakukan pada bulan Januari sampai Maret 2015. Dengan fokus pada proses komunikasi yang berlangsung antara seksi Informasi dan seksi Lantaskim di Kantor Imigrasi Kelas 1
Jakarta Pusat. Dimana peneliti mencoba menjelaskan mengenai jenis, bentuk faktor dan hambatan komunikasi internal yang menjadi penyebab misunderstanding. Teknik pengumpulan data menggunakan purposive sampling dan Prinsip analisis datanya adalah menggunakan interaktif model. Dengan gambar sebagai berikut :

\section{Gambar 1 Analisis Data Model Interaktif Miles dan Huberman}

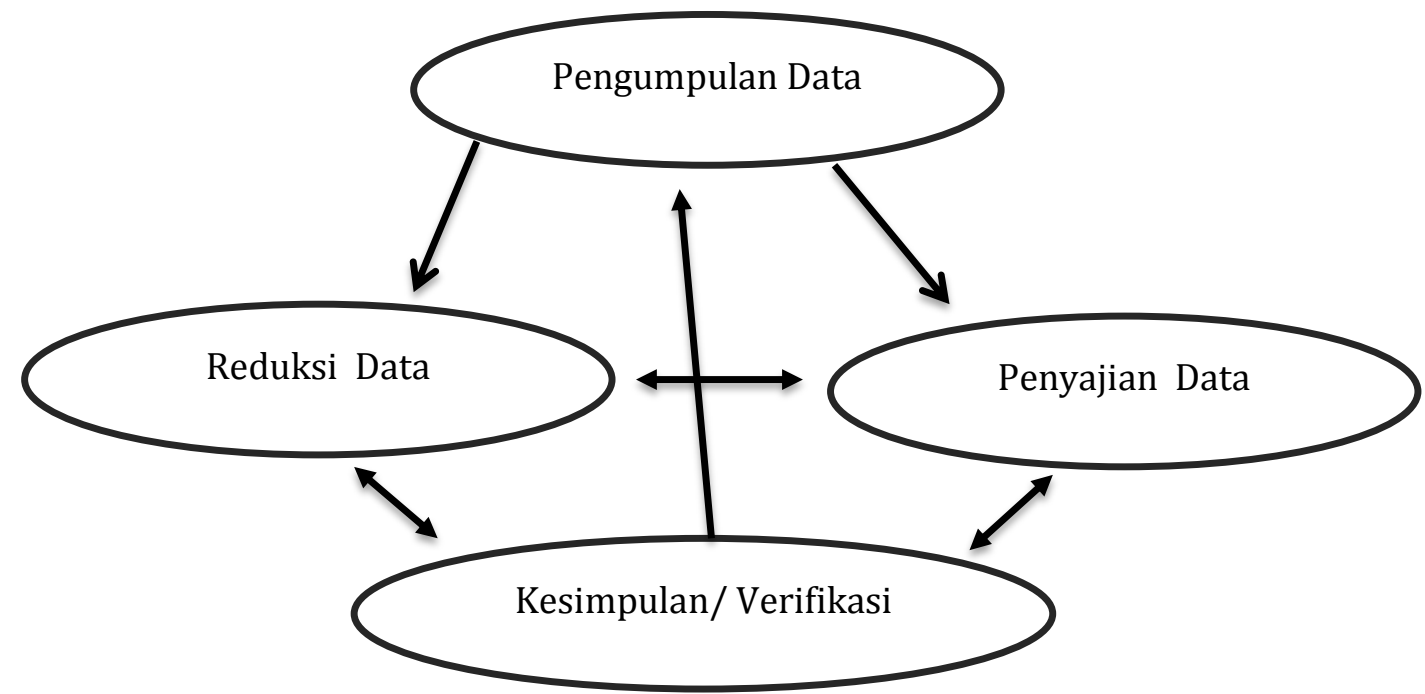

HASIL DAN PEMBAHASAN

\section{Bentuk dan Media Komunikasi}

Komunikasi yang terbentuk antara Seksi

Informasi dan Sarana Komunikasi dan Seksi
Lalu Lintas Keimigrasian adalah komunikasi langsung dan menggunakan media telepon. Yang dirincikan pada tabel berikut ;

Tabel 1. Jenis Komunikasi langsung dan bermedia

\begin{tabular}{|c|c|c|}
\hline \multirow[t]{2}{*}{ Bentuk Komunikasi } & \multicolumn{2}{|c|}{ Jenis Komunikasi } \\
\hline & Komunikasi Langsung & Komunikasi Bermedia \\
\hline $\begin{array}{l}\text { saat peohon komplain melalui } \\
\text { Costumer service atau petugas } \\
\text { piket yang berada di lantai } 1 \\
\text { kita tanganni, kalau memang } \\
\text { mereka masih belum puas } \\
\text { dengan jawaban dari petugas, } \\
\text { kami arahkan kepada seksi } \\
\text { Insarkom selaku seksi yang }\end{array}$ & V & \\
\hline
\end{tabular}




\begin{tabular}{|c|c|c|}
\hline \multicolumn{3}{|l|}{$\begin{array}{l}\text { berfungsi untuk menyebarkan } \\
\text { informasi dan memberikan } \\
\text { penjelesan } \\
\text { pelayanan kantor ini, lalu } \\
\text { dikoordinasikan kembali ke } \\
\text { seksi kami. }\end{array}$} \\
\hline $\begin{array}{lr}\text { komunikasi yang berlangsung } \\
\text { dengan Seksi Lantaskim } \\
\text { mengenai } \\
\text { komplainan } \\
\text { komunikasiah langsung atau face } \\
\text { to face dan kadang } \\
\text { menggunakan media yaitu via } \\
\text { line telepon kepada kasubsi } \\
\text { Lantaskim }\end{array}$ & V & V \\
\hline $\begin{array}{l}\text { dari CS atau petugas piket } \\
\text { dibawa ke Seksi Insarkom dan } \\
\text { dari seksi Insarkom yang } \\
\text { diwakili oleh Kepala Sub } \\
\text { Sesksi nya menghubungi via } \\
\text { telephone atau nyamperin } \\
\text { langsung keruangannya" }\end{array}$ & V & $\mathrm{V}$ \\
\hline 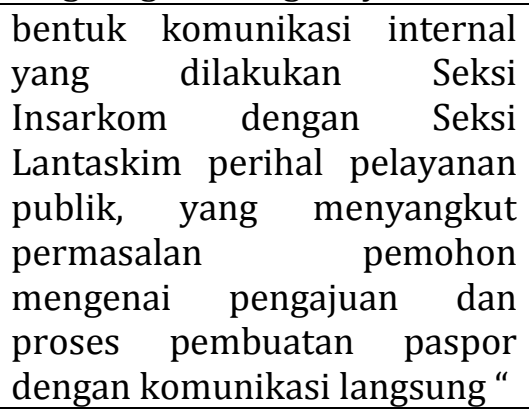 & V & $\mathrm{V}$ \\
\hline $\begin{array}{lr}\text { komunikasi } & \text { dengan seksi } \\
\text { Lantaskim } & \text { menyangkut } \\
\text { permasalan } & \text { pemohon } \\
\text { mengenai complain/keluhan } \\
\text { terhadap pengajuan dan } \\
\text { proses pembuatan paspor, } \\
\text { seringnya si langsung aja kalau } \\
\text { telephone kadang-kadang }\end{array}$ & V & $\mathrm{V}$ \\
\hline
\end{tabular}

\section{Isi Pesan Yang Dikomunikasikan}

Isi pesan yang dikomunikasikan oleh seksi Lantaskim kepada seksi Insarkom atau sebaliknya mengenai pemohon jasa Keimigrasian yang mengajukan complain dan keluhannya yaitu mengenai permasalahan sistem pelayanan paspor terpadu (one stop service) belum bisa melakukan penentuan kuota, permasalahan penentuan tanggal datangnya pemohon dan E-Paspor yang tidak bisa melewati Autogat.

\section{Aktor yang berkomunikasi}

Aktor yang melakukan proses komunikasi terhadap pelayanan masyarakat adalah pihak Seksi Lantaskim yaitu Petugas piket, costumer service, pemegang sistem OSS, Kepala Seksi dan Kepala Sub Seksi Lalu Lintas Keimigrasian. Sedangkan pada Seksi Informasi dan Sarana Komunikasi ialah Kepala Sub Seksi Informasi dan di dampingi staf Insarkom untuk membantu memeriksa aplikasi dari pemohon. Aktor-aktor ini berperan sebagai pengirim pesan atau 
penerima pesan. Aktor-aktor ini berfungsi sebagai pemberi informasi terhadap kebutuhan penerima jasa Keimigrasian dan yang mengani komplainan atau keluhan.

Tabel 2 Aktor yang berperan dalam penangan pengaduan masyarakat

\begin{tabular}{|c|c|c|c|}
\hline \multirow[t]{2}{*}{ Aktor } & \multirow[t]{2}{*}{ Keterangan } & \multicolumn{2}{|c|}{ Standar Operasional Prosedur } \\
\hline & & $\begin{array}{l}\text { Deskripsi dan } \\
\text { Informasi } \\
\end{array}$ & Legalisasi \\
\hline \multirow{4}{*}{$\begin{array}{l}\text { Pihak Seksi Lalu } \\
\text { Lintas Keimigrasian }\end{array}$} & $\begin{array}{l}\text { Kepala sub seksi } \\
\text { Lantaskrim }\end{array}$ & & V \\
\hline & $\begin{array}{l}\text { Staf pemegang sistem } \\
\text { OSS }\end{array}$ & & V \\
\hline & Costomer Service & & $\mathrm{V}$ \\
\hline & Petugas piket & & $\mathrm{V}$ \\
\hline \multirow{3}{*}{$\begin{array}{l}\text { Pihak sekse } \\
\text { informasi dan } \\
\text { sarana komunikasi }\end{array}$} & $\begin{array}{l}\text { Kepala seksi } \\
\text { informasi dan sarana } \\
\text { komunikasi }\end{array}$ & V & \\
\hline & $\begin{array}{l}\text { Kepala seksi } \\
\text { informasi dan sarana } \\
\text { komunikasi }\end{array}$ & V & \\
\hline & $\begin{array}{l}\text { Staf seksi informasi } \\
\text { dan sarana } \\
\text { komunikasi untuk } \\
\text { verivikasi data }\end{array}$ & V & \\
\hline
\end{tabular}

\section{Frekuensi berkomunikasi}

Frekuensi yang terjadi antara seksi Lalu Lintas Keimigrasian dengan Seksi Informasi dan Sarana komunikasi secara formal yang menyangkut pekerjaan tidak ada. Intensitas pertemuan hanya terjadi apabila ada masyarakat yang mengajukan pertanyaan/komplain.

\section{Jenis Hubungan}

komunikasi memainkan peran sebagai penghubung antara unit satu dengan unit lainnya. Jenis hubungan yang dilakukan oleh Seksi Lalu Lintas Keimigrasi dan Seksi Informasi dan Sarana Komunikasi yaitu menggunakan komunikasi interpersonalsecara face to face dan Kasubsi Informasi menggunakan via line telepon Jenis hubungan ini terbentuk dari proses konfirmasi pemohon paspor saat menghadap petugas Costumer service maupun pada petugas piket jika pemohon yang komplain tidak puas di alihkan kepada Seksi Informasi dan Sarana Komunikasi. 
Gambar 2 Pola Komunikasi antara Seksi Lantaskim dan Seksi Insarkom

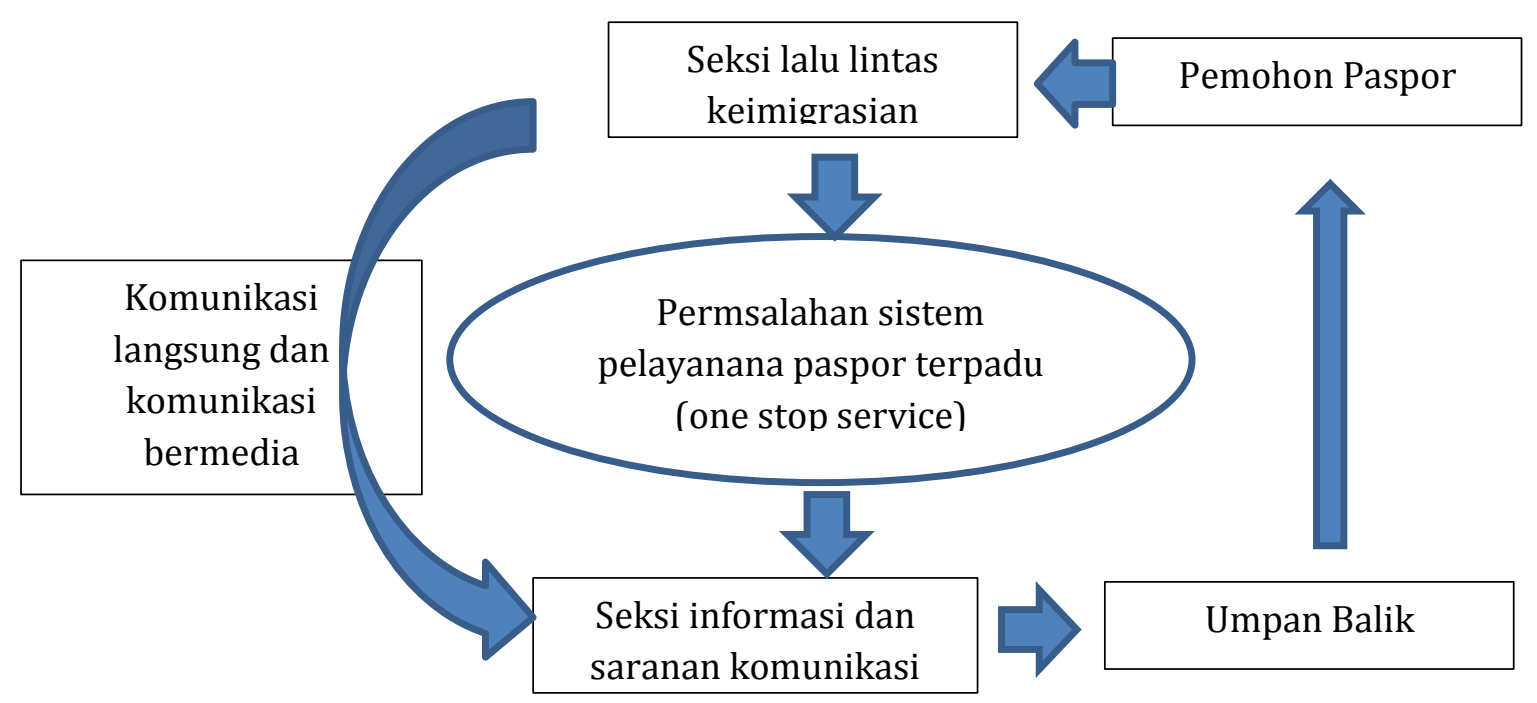

\section{Jenis Komunikasi Internal Antar Seksi}

Komunikasi internal yang berlangsung antara Seksi Insarkom dan Seksi Lantaskim diklasifikasikan menjadi dua jenis yaitu komunikasi personal dan komunikasi kelompok. Dari hasil data menerangkan bahwa dalam menangani masalah komplainan pemohon jasa Keimigrasian mengenai prosedur pelayanan paspor one stop service dilakukan komunikasi personal yaitu face to face atau langsung dan menggunakan komunikasi bermedia yaitu line telepon.

\section{Bentuk Komunikasi Antar Seksi}

Bentuk komunikasi yang berlangsung diantara kedua seksi mengalir dari bawah ke atas dan atas kebawah yang menggambarkan hubungan kerja antara bawahan dan atasan, bentuk komunikasi ini berjalan dalam proses pelayanan paspor. Komunikasi horizontal dan diagonal terlihat saat pengiriman serta penerimaan pesan informasi yang dilakukan antara berbagai anggota organisasi yang memiliki kedudukan yang sama antara staf pelayanan dengan staf pemagang sistem OSS.

\section{Faktor Pendorong Dan Hambatan Komunikasi Internal}

\section{A. Faktor Pendorong Misunderstanding}

Berdasarkan teori komunikasi organisasi dijelaskan mengenai proses interaksi yang terjadi pada orang-orang yang menjadi bagian dalam organisasi. Teori tersebut ternyata sesuai dengan objek yang diteliti, bahwa seksi Lantaskim dan seksi Insarkom mengalami kendala dalam berkomunikasi. Kesalahpahaman/misunderstanding yang terjadi di Seksi Lantaskim dan Seksi Insarkom berdasarkan hasil wawancara dari lima informan terjadi karena beragam faktor dan hambatan yang disebabkan kurangnya intensitas komunikasi.

Kegagalan komunikasi ini disebabkan karena kedua seksi belum pernah mengadakan briefing,meeting dan coffee morning sehingga membuka jurang perbedaan persepsi diantara kedua seksi tersebut. Padahal fungsi komunikasi sendiri untuk mengurangi tingkat ketidakpastian. Keadaan ini memperlihatkan komunikasi hanya berjalan satu arah di antara kedua seksi tersebut. Sehingga terdapat beberapa faktor yang menyebabkan terjadinya misunderstanding dalam komunikasi internal antar seksi, yaitu: 
1. Intensitas komunikasi yang kurang dalam penyampain isi pesan

2. Sasaran manajemen kantor yang kurang terkoordinasi

3. Pembagian kinerj/job desk yang belum terintegrasi

\section{B. Hambatan Komunikasi Internal}

Hambatan ini peneliti analisis dari segi proses komunikasi yaitu penyampaian informasi dari seksi Lantaskim kepada seksi Insarkom atau sebaliknya berdasarkan hasil wawancara dan observasi dilapangan. Setelah mendapatkan hasil ternyata diketemukan hambatan komunikasi yang terjadi diantara seksi Lantaskim dan seksi Insarkom berasal dari hambatan individual dan hambatan mekanis. Berikut hasil analisis peneliti:

1. Penafsiran (Selective Perception)

Setiap orang memiliki penafsiran yang berbeda-beda, sehingga penafsiran terhadap suatu pesan yang sama dapat berbeda-beda, Mekanisme umpan balik dalam kedua unit seksi tersebut kurang terkoordinasi ini yang menjadi hambatan individual yang disebabkan Perbedaan dasar pandangan.

2. Faktor Empathy, Responsive dan Reliability

Pada unit seksi yang di analisis kurangnya empati, Responsive, Reliability yang dilakukan aktor-aktor yang diberi tanggung jawab sebagai petugas yang melayani pemohon paspor yang komplain/mengeluh sehingga tidak ada keberhasilan dalam komunikasi yang efektif diantara kedua unit seksi tersebut dalam sebuah organisasi.

3. Tidak ada penentuan waktu yang efektif

Misunderstanding terjadi dalam komunikasi antar pribadi dimana analisis peneliti melihat kurangnya koordinasi setelah menyampaikan pesannya. Tidak ada komunikasi

yang efektif dalam penangan masalah komplain dan tidak terlihat waktu untuk berdiskusi secara komunikatif sehingga tidak terlihat komunikasi dua arah berjalan secara efektif.

4. Mengatur arus informasi

Misunderstanding ini terjadi karena belum terlihatnya ruang untuk mengatur arus informasi. Volume pekerjaan yang tinggi pada masingmasing unit menyebabkan penyampaian informasi hanya berjalan selentingan dan manajemen komplain tidak terorganisir dengan baik.

5. Jarak antar unit yang berjauhan

Dari hasil pengamatan peneliti faktor hambatan lainnya dari hambatan mekanis yaitu jarak antar unit yang berjauhan. Seksi Lantaskim yang berada di lantai dua dan Seksi Insarkom berada di lantai empat menyebabkan kedekatan emosional dalam hubungan komunikasi interpersonal yang dilakukan oleh staf diantara dua unit tersebut jarang dilakukan.

Sehingga dapat disimpulkan bahwa hambatan komunikasi yang menyebabkan adanya misunderstanding disebabkan faktor individual yaitu oleh perbedaan Penafsiran (Selective Perception). Faktor individual meliputi Empathy, Responsive dan Reliability dan faktor mekanis yang disebabkan oleh struktur organisasi atau fungsi manajemen organisasi yang kaku dan jarak bicara antar seksi yang berjauhanan.

Dengan demikian permasalahan komunikasi internal yang dialami oleh Seksi Lantaskim dan Seksi Insarkom dapat diminimalisir dengan memanfaatkan adanya forum/rapat yang fokus membahas mengenai permasalahan komplain atau keluhan dari masyarakat. 


\section{KESIMPULAN DAN SARAN}

\section{Kesimpulan}

Berdasarkan penelitian yang dilakukan di Kantor Imigrasi Kelas 1 Jakarta Pusat pada Seksi Lalu Lintas Keimigrasian dan Seksi Informasi dan Sarana Komunikasi mengenai komunikasi internal dalam meningkatkan pelayanan publik, peneliti menyimpulkan :

1. Jenis dan Bentuk komunikasi antar seksi a). Komunikasi internal yang berlangsung antara Seksi Insarkom dan Seksi Lantaskim diklasifikasikan menjadi dua jenis yaitu komunikasi personal dan komunikasi kelompok. Komunikasi personal ini berlangsung dengan cara face to face dan menggunakan media komunikasi yaitu line telepon. Sedangkan komunikasi kelompok berlangsung antara Seksi Lantaskim dan Seksi Insarkom dalam mengkoordinasikan isi pesan mengenai pertanyaan maupun keluhan pemohon jasa keimigrasian. b). Bentuk komunikasi yang berlangsung diantara kedua seksi mengalir dari bawah ke atas dan atas kebawah yang menggambarkan hubungan kerja antara bawahan dan atasan, bentuk komunikasi ini berjalan dalam proses pelayanan paspor. Dan bentuk komunikasi horizontal atau diagonal terlihat saat pengiriman serta penerimaan pesan informasi yang dilakukan antara berbagai anggota organisasi yang memiliki kedudukan yang sama antara staf pelayanan dengan staf pemagang sistem OSS.

2. Faktor dan Hambatan yang terjadi dalam mengkoordinasikan komunikasi personal atau kelompok meliputi kurangnya intensitas berkomunikasi personal, dan perbedaan argument. Sedangkan hambatanya dikarenakan hambatan individual meliputi faktor Reliability, Responsiveness dan Empathy sehingga komunikasi tidak berjalan two way traffic communication dan hambatan mekanis yang disebabkan karena struktur organisasi dan jarak lokasi seksi yang berjauhan.

\section{Saran}

Saran yang dapat dipaparkan berdasarkan dari hasil observasi dan pembahasan analisis komunukasi internal yang dilakukan peneliti sebagai berikut :

1. Sebaiknya untuk meminimalisir misunderstanding antara seksi Lantaskim dan seski Insarkom perlu diadakannya program komunikasi internal seperti briefing/rapat, coffee morning yang diadakan sebulan sekali untuk membahas masalah keluhan/komplainan dari masyarakat atas pelayanan yang diberikan dan permasalahan anatara seksi Lantaskim dan seksi Insarkom tentang perbedaan argumen mengenai standar operasional persedur dalam menentukan kebijakan yang akan diberikan kepada pemohon demi meningkatnya kualitas pelayanan publik yang diberikan Kantor Imigasi Kelas 1 Jakarta Pusat.

2. Perlunya peningkatan kinerja pegawai melalui training atau pelatihan khusus seperti workshop, study tour mengenai komunikasi yang baik dan efektif untuk Seksi Lalu Lintas Keimigrasian dan Seksi Informasi dan Sarana Komunikasi agar masalah keluhan atau komplainan dari pemohon paspor dapat ditangani dengan terintegrasi.

\section{DAFTAR PUSTAKA}

Abdullah Z \& Antony CA . 2012. Perceptions of Employees on Internal Communication of a Leading Five Star Hotel in Malaysia. 17-26

Arni M. 2005. Komunikasi Organisasi. Jakarta: Bumi Aksara.

Buchari A. 2011.Manajemen Pemasaran dan Pemasaran Jasa, Bandung: Penerbit Alfabeta. 
Effendy OU. 1997. Ilmu Komunikasi Teori dan Praktek, Cetakan Ke-sepuluh. Bandung: PT. Remaja Rosdakarya.

Effendy OU. 2003. Ilmu komunikasi Teori dan Praktik, Bandung: PT.Remaja Rosdakarya.

Effendy OU. 2006. Ilmu Komunikasi Teori dan Praktek. Bandung: PT Remaja Rosdakarya.

Erhanda Pungky Febrian Putra. 2014. Analisis Aliran Informasi Kegiatan Perusahaan Pada Program Komunikasi Internal Bagi Karyawan Mobil Cepu Limited Bojonegoro. Malang. Universitas Brawijaya.

Gibson dkk. 1997. Organisasi : Perilaku, Struktur, Proses, Edisi Kedelapan Jilid 2, Alih Bahasa Nunuk Adiarni, Jakarta: Erlangga.

Hamidi.2005. Metode Penelitian Kualitatif, Malang: UMM.

Kalmi Hartati. 2013. Pola Komunikasi Antara staf dan Lurah di Kantor Kelurahan Perangat Selatan Kecamatan Marangkayu Kabupaten Kutai Kartanegara. Palangkaraya. Universitas Mulawarman.

Littlejohn SW \& Karen AF. 2009. Teori Komunikasi (Theories of Human Communication) edisi 9. Jakarta: Salemba Humanika.

Mulyana D. 2001. Ilmu Komunikasi Suatu Pengantar. Bandung: PT Remaja Rosdakarya.

Poerwandari EK.1998. Pendekatan Kualitatif dalam Penelitian Psikologi. Jakarta: LPSP3 Fakultas Psikologi Universitas Indonesia.

Rasyid MR. 1998. Desentralisasi Dalam Menunjang Pembangunan Daerah dalam Pembangunan Administrasi Di Indonesia, Jakarta: Pustaka LP3ES

Ramandita Rahajeng. 2012. Hubungan Komunikasi Internal dan Employee
Engagement di PT.PLN (Persero) Area

Bekasi. Depok. Universitas Indonesia.

Robbins SP. 2006. Perilaku Organisasi (alih bahasa Drs. Benjamin Molan),Edisi Bahasa Indonesia, Klaten: PT. Intan Sejati.

Roger ME \& Kincaid LD. 1981. Communication Network Toward a New Paradigm For Research. New York: The Free Press a Divission of Macmillan Publishing.

Stewart LT \& Sylvya M. 2005. Human Communication Konteks-Konteks Komunikasi , Bandung. Penerbit PT. Rosda Karya.

Stoner F \& Gilbert. 1996. Manajemen, Jilid II, Alih Bahasa Alexander Sindoro, , Jakarta: Prenhallindo.

Sugiyono. 2005. Metode Penelitian Kualitatif, Bandung: Alfabeta.

Sugiyono.2008. Metode Penelitian Kuantitatif Kualitatif Dan R\&D, Bandung: Alfabeta.

Tjiptono. 2006. Manajemen Sumber Daya Manusia Untuk Perusahaan: Dari Teori Ke Praktik. Jakarta: Raja Grafindo.

Wiryanto. 2004. Pengantar Ilmu Komunikasi, Jakarta: Grasindo.

Yulianita N. 2007. Dasar-dasar Public Relations.Bandung: Pusat PenerbitanUniversitas (LPU) Lembaga Penelitian dan Pengabdian .

Welch M., and Jackson PR. 2007. Rethinking Internal Communication: a Stakeholder Welch, M., and Jackson, P.R. 2007. Rethinking Internal Communication: a Stakeholder Approach, Corporate Communications: An International Journal, Vol. 12 No. 2, pp. 177-198. 